\title{
PENGARUH CITRA MEREK DAN KUALITAS PELAYANAN TERHADAP LOYALITAS PELANGGAN MELALUI VARIABEL KEPUASAN PELANGGAN
}

\author{
Januar Habibi Mahsyar \\ januar.habibi@uniku.ac.id \\ Prodi Manajemen Fakultas Ekonomi \\ Universitas Kuningan
}

\begin{abstract}
PT Pos Indonesia (Persero) as a State-Owned Enterprise (BUMN) which carries out the mission of postal mail and postal parcel courier services in Indonesia with premium products, Special Express Post is a delivery service with a maximum travel time of 4 days that reaches the recipient quickly, precise, safe and reach all parts of Indonesia. One strategy to foster customer satisfaction that leads to customer loyalty is the formation of a brand image and the best possible service quality in the minds of postal customers.

The research method used in this research is descriptive verification with a quantitative approach, to determine the significant relationship between the variables of brand image, service quality to customer satisfaction and customer loyalty. The population in this study were customers of the Kuningan Post Office, users of special express mail delivery services, amounting to 1,769. Techniques and data sources were obtained from literature studies and questionnaires to 298 respondents who were designated as samples with a significance level of $5 \%$.

The results of the hypothesis test indicate that the variables of brand image and service quality partially have a positive and significant effect on customer satisfaction. Customer satisfaction variables partially have a positive and significant effect on customer loyalty. Brand image variables partially have a positive and significant effect on customer loyalty. Service quality variable partially does not have a significant effect on customer loyalty. Simultaneously, brand image and service quality have a positive effect on customer satisfaction and loyalty.
\end{abstract}

Keywords: Brand Image; Service Quality, Customer Satisfaction, Customer Loyalty.

\section{PENDAHULUAN}

PT Pos Indonesia (Persero) sebagai Badan Usaha Milik Negara (BUMN) yang mengemban misi layanan jasa kurir surat pos dan paket pos di Indonesia dengan produk premium Pos Kilat Khusus merupakan layanan jasa pengiriman dengan waktu tempuh maksimal 4 hari telah sampai pada penerima secara tepat, aman dan menjangkau seluruh wilayah Indonesia.
Seperti yang dilansir dalam koran harian online industry.bisnis.com dijelaskan bahwa market share perusahaan jasa kurir Indonesia masih dipegang oleh PT Jalur Nugraha Ekakurir (JNE). Berdasarkan data terlihat bahwa $41 \%$ market share di raih oleh JNE, 20\% oleh Pos Indonesia, 14\% Tiki, 10\% J\&T 3\% oleh DHL dan $10 \%$ oleh Jasa Kurir lainnya.

Potensi pasar bisnis jasa kurir di Kabupaten Kuningan masih memiliki peluang yang besar seperti hasil penelitian awal yang dilakukan oleh penulis terhadap 30 responden 
Indonesian Journal Of Strategic Management Vol 3, Issue 2, Agustus 2020

yang bertujuan untuk mengetahui potensi pasar dan (market share) di Kantor Pos Kuningan 4550, dijelaskan bahwa $70 \%$ pelanggan melakukan pengiriman rata-rata lebih dari 3 kali dalam waktu 1 tahun, dan $20 \%$ menyebutkan 2 kali dalam 1 tahun dan $10 \%$ menyebutkan akan menggunakan jasa pengiriman ketika dibutuhkan.

Hasil lain menyebutkan bahwa 70\% responden menyatakan puas dengan kualitas pelayanan yang diberikan saat menggunakan layanan Surat \& Paket Pos jika dinilai dari segi keramahan petugas, ketepatan waktu penyampaian kiriman, dan keamanan. 20\%
p-ISSN 2614-5391, e-ISSN 2614-2406 https://journal.uniku.ac.id/index.php/ijsm

menyatakan cukup puas dan $10 \%$ merasa tidak puas dengan kualitas pelayanan Pos Kilat Khusus karena masih terdapat keterlambatan penyampaian hingga lebih dari satu hari dari waktu yang telah ditetapkan.

\section{TINJAUAN PUSTAKA}

Menurut Kotler dan Keller (2007:17) "pemasaran adalah proses perencanaan dan pelaksanaan konsepsi, penetapan harga, promosi, dan distribusi gagasan barang dan jasa untuk menciptakan pertukaran yang memuaskan tujuan individu dan organisasi”.

\section{Kerangka Berfikir}

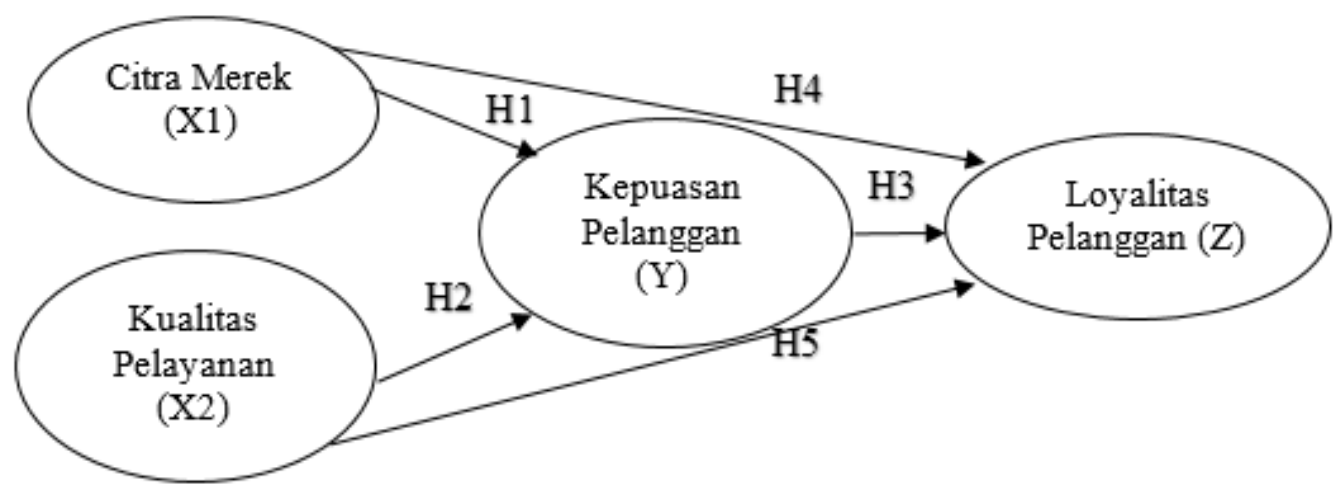

Gambar 2

Kerangka Pemikiran Penelitian

\section{HIPOTESIS PENELITIAN}

Berdasarkan kerangka pemikiran, maka hipotesis penelitian ini adalah sebagai berikut :

H1 = Terdapat pengaruh signifikan antara Citra Merek terhadap Kepuasan Pelanggan.

$\mathbf{H 2}=$ Terdapat pengaruh signifikan antara Kualitas Pelayanan terhadap Kepuasan Pelanggan

$\mathbf{H 3}=$ Terdapat pengaruh signifikan antara kepuasan pelanggan terhadap loyalitas pelanggan

H4 = Terdapat pengaruh signifikan antara Citra Merek terhadap Loyalitas Pelanggan
H5 = Terdapat pengaruh signifikan antara Kualitas Pelayanan terhadap Loyalitas Pelanggan

H6 = Secara bersama-sama citra merek dan kualitas pelayanan memiliki pengaruh signifikan terhadap kepuasan pelanggan.

H7 = Secara bersama-sama citra merek dan kualitas pelayanan memiliki pengaruh signifikan terhadap kepuasan pelanggan.

\section{METODE PENELITIAN}

Dalam hal ini, penulis menggunakan penelitian motode deskriptif verifikatif merupakan metode yang bertujuan menggambarkan benar atau tidaknya fakta-fakta 
Indonesian Journal Of Strategic Management Vol 3, Issue 2, Agustus 2020

yang ada, serta menjelaskan tentang hubungan antar variable yang diteliti dengan cara mengumpulkan data, mengolah, menganalisis dan menginterprestasi data dalam pengujian hipotesis statistik. Oleh sebab itu, dalam penulisan penelitian ini untuk menggali tentang

\section{POPULASI \& SAMPEL}

Dalam penelitian ini populasi yang digunakan adalah jumlah pelanggan pengguna jasa pengiriman PT Pos Indonesia (Persero) Kantor Pos Kuningan 45500 yang berjumlah 1.769 Pelanggan. Jumlah sampel yang ditentukan dalam penelitian ini yaitu sebanyak 298 Orang Responden Pengguna Jasa Produk Surat Pos dan Paket Pos Kilat Khusus di Kantor Pos Kuningan 45500 .

\section{MODEL STRUKTURAL \& SEM ANALISIS}

p-ISSN 2614-5391, e-ISSN 2614-2406 https://journal.uniku.ac.id/index.php/ijsm

pengaruh Citra Merek dan Kualitas Pelayanan Terhadap Loyalitas Pelanggan Melalui Kepuasan Pelanggan dengan menggunakan Structural Equation Modeling (SEM) dengan studi kasus pada PT Pos Indonesia (Persero) Kantor Pos Kuningan 45500.

Pengolahan data dalam penelitian ini menggunakan program Analysis of Moment Structure (AMOS) 24 yang merupakan program statistic untuk mengalisis Structural Equation Modeling (SEM) yang mampu memberikan model secara konfirmatori dan ekploratori.

Berikut ini model structural dengan variabel laten terdiri dari bagian model pengukuran (measurement model) yaitu hubungan dari indicator ke variabel-variabel laten dan model structural yaitu hubungan antar variabel laten.

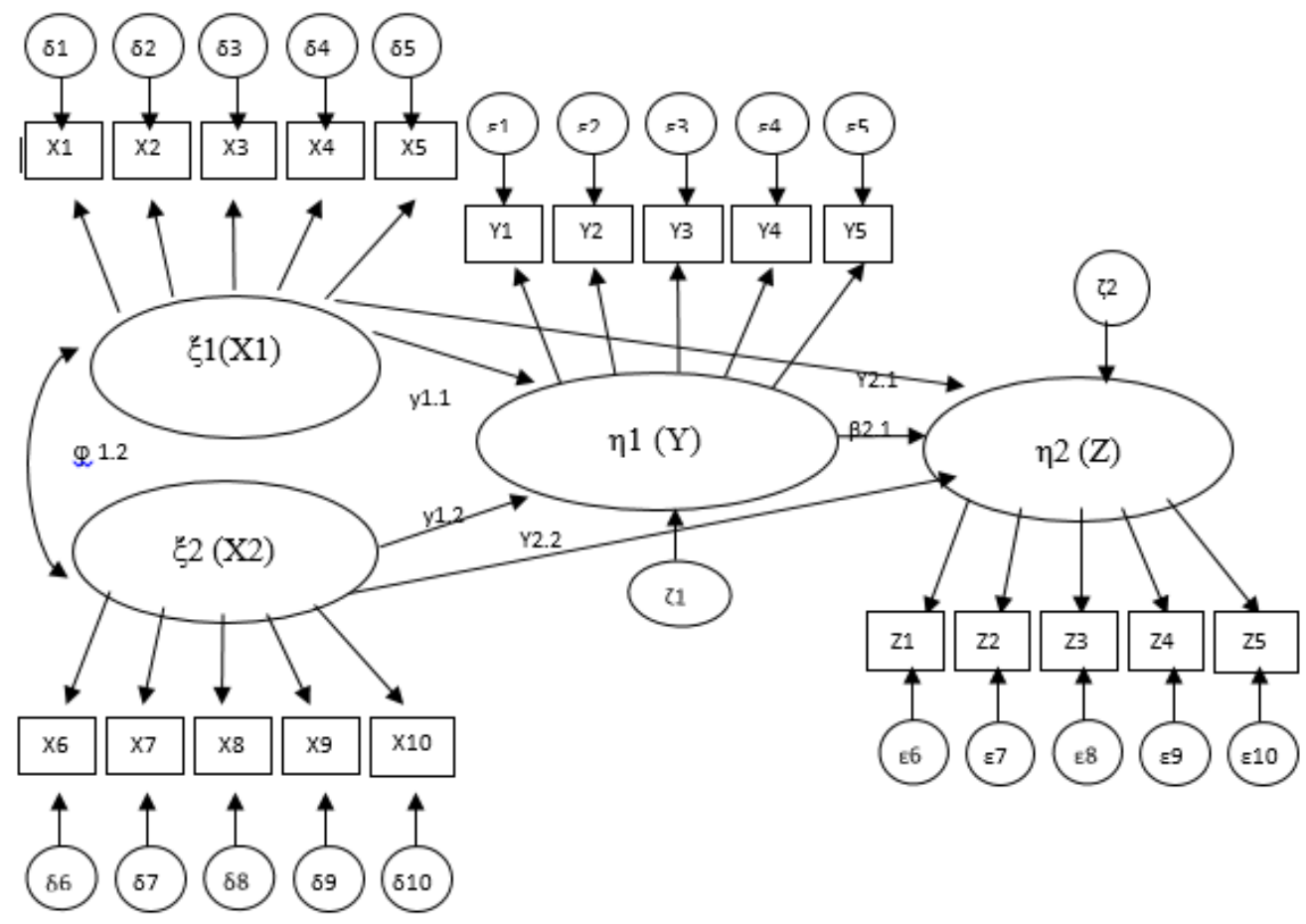

Gambar 3

Model Structural Dengan Variabel Laten

Berdasarkan Gambar 3 tersebut dapat 1. Terdapat dua variabel exogen laten yaitu $\xi 1$ dijelaskan hal-hal sebagai berikut : (ksi1)(Citra Merek) dan $\xi 2$ (ksi2) (Kualitas Pelayanan) masing-masing variabel diukur 
Indonesian Journal Of Strategic Management

Vol 3, Issue 2, Agustus 2020

dengan indicator atau manifest. Simbol manifest untuk variabel exogen adalah $\mathrm{X}$ dan nilai errornya disebut delta $(\delta)$

2. Tedapat dua variabel endogen laten yaitu $\eta 1($ eta1)(Kepuasan) dan $\eta 2$ (eta2) (Loyalitas) masing-masing variabel diukur dengan indicator atau manifest. Simbol manifest untuk variabel endogen adalah nilai errornya disebut epsilon $(\varepsilon)$

3. Antar variabel laten exogen dikovariankan dengan saling menghubungkan kedua varibel laten ini dengan dua anak panah (hubungan kovarian atau korelasi) dengan sibol phi $(\varphi)$

4. Semua varibel laten endogen harus diberi error atau nilai residual regression dengan symbol zeta $(\zeta)$

5. Koefisien regresi antar variabel laten exogen dengan variabel laten endogen diberi symbol gama $(\gamma)$ dengan cara memberi notasi dari varibel laten endogen ke variabel laten exogen :

$$
\begin{aligned}
& \text { Variabel Laten } \xi 1: \\
& \mathrm{X} 1=\lambda 1.1 \xi 1+\delta 1 \\
& \mathrm{X} 2=\lambda 2.1 \xi 1+\delta 2 \\
& \mathrm{X} 3=\lambda 3.1 \xi 1+\delta 3 \\
& \mathrm{X} 4=\lambda 4.1 \xi 1+\delta 4 \\
& \mathrm{X} 5=\lambda 5.1 \xi 1+\delta 5 \\
& \text { Variabel Laten } \eta 1 \\
& \mathrm{Y} 1=\lambda 1.1 \eta 1+\varepsilon 1 \\
& \mathrm{Y} 2=\lambda 2.1 \eta 1+\varepsilon 2 \\
& \mathrm{Y} 3=\lambda 3.1 \eta 1+\varepsilon 3 \\
& \mathrm{Y} 4=\lambda 4.1 \eta 1+\varepsilon 4 \\
& \mathrm{Y} 5=\lambda 5.1 \eta 1+\varepsilon 5
\end{aligned}
$$

8. Model persamaan structural adaah model hubungan antar variabel laten dengan persamaan sebagai berikut :

\section{HASIL DAN PEMBAHASAN}

\subsubsection{Hasil Analisis Structural Equation Modeling (SEM)}

Analisis ini digunakan untuk mengetahui hubungan struktural antara variabel yang diteliti.
p-ISSN 2614-5391, e-ISSN 2614-2406

https://journal.uniku.ac.id/index.php/ijsm

Dari $\xi 1$ ke $\eta 1=\gamma 1.1$

Dari $\xi 2$ ke $\eta 1=\gamma 1.2$

Dari $\xi 1$ ke $\eta 2=\gamma 2.1$

Dari $\xi 2$ ke $\eta 2=\gamma 2.2$

6. Koefisien regresi antar varibel laten endogen dengan variabel laten endogen lainnya diberi symbol beta $(\beta)$ dengan cara memberi notasi sebagai berikut:

Dari $\eta 1$ ke $\eta 2=\beta 2.1$

7. Ada dua model pengukuran (measurement model) yaitu model pengukuran variabel laten exogen dan model pengukuran variabel laten endogen. Model pengukuran adalah hubungan antar indicator atau manifest dengan konstruk latennya. Berdasarkan gambar 3.1. tersebut terdapat dua pengukuran laten exogen $\xi 1$ dan $\xi 2$, serta dua model pengukuran variabel laten endogen $\eta 1$ dan $\eta 2$. Nilai factor loading dari indicator ke konstruk laten disebut lambda $(\lambda)$. Berikut ini persamaan matematik model pengukuran:

$$
\begin{aligned}
& \text { Variabel Laten } \xi 2: \\
& \mathrm{X} 6=\lambda 6.2 \xi 2+\delta 6 \\
& \mathrm{X} 7=\lambda 7.2 \xi 2+\delta 7 \\
& \mathrm{X} 8=\lambda 8.2 \xi 2+\delta 8 \\
& \mathrm{X} 9=\lambda 9.2 \xi 2+\delta 9 \\
& \mathrm{X} 10=\lambda 10.2 \xi 2+\delta 10
\end{aligned}
$$

Variabel Laten $\xi 2$ :

$\mathrm{Z} 1=\lambda 6.2 \eta 2+\varepsilon 1$

$\mathrm{Z} 2=\lambda 7.2 \eta 2+\varepsilon 2$

$\mathrm{Z} 3=\lambda 8.2 \eta 2+\varepsilon 3$

$\mathrm{Z} 4=\lambda 9.2 \eta 2+\varepsilon 4$

$\mathrm{Z} 5=\lambda 10.2 \eta 2+\varepsilon 5$

$$
\begin{aligned}
& \eta 1=\gamma 1.1 \xi 1+\gamma 1.2 \xi 2+\varsigma 1 \\
& \eta 2=\gamma 2.1 \xi 1+\gamma 2.2 \xi 2+\varsigma 1+\beta 2.1 \eta 1+\varsigma 2
\end{aligned}
$$

Hubungan struktural yang terjadi antara variabel dapat diuji kesesuaiannya dengan goodness of fit index. Hasil analisis SEM dalam penelitian ini dapat dilihat pada gambar berikut ini : 


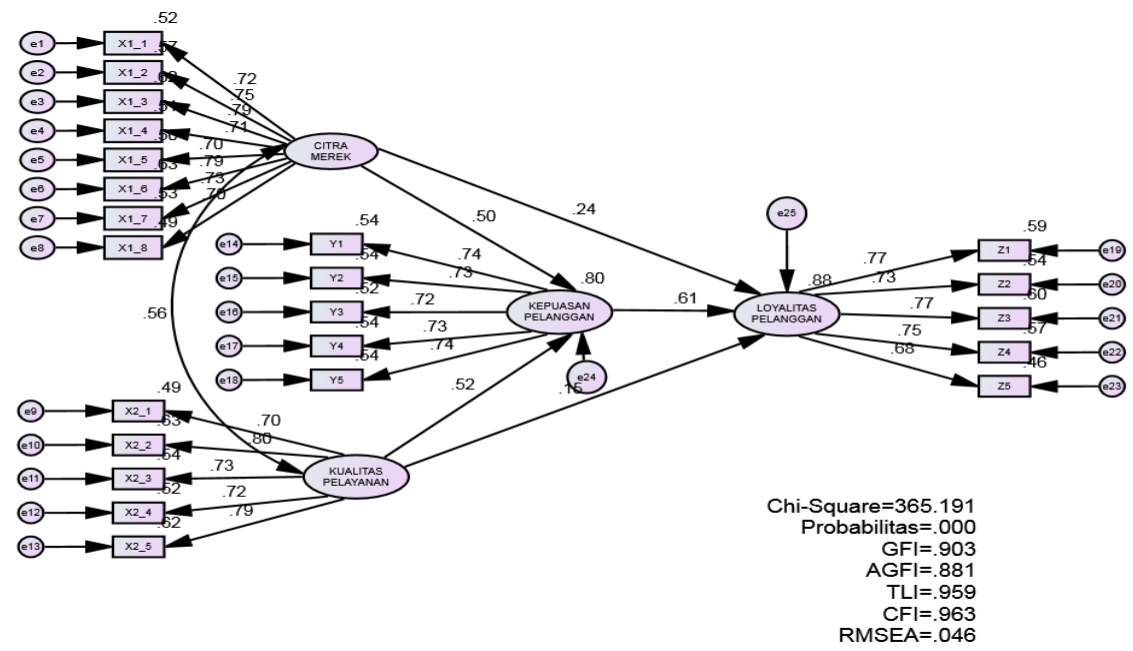

Gambar 4

Hasil Uji Full Model Structural Equation Modeling (SEM)

Berdasarkan gambar 4.28 Full Model Structural Equation Modeling (SEM) dapat diketahui hasil chi square sebesar 365,191 dengan probabilitas $0,000<0,05$, nilai RMSEA sebesar $0,046 \leq 0,08$, nilai GFI sebesar $0,903 \geq$ 0,90 , nilai AGFI sebesar $0,881<0,90$, nilai TLI sebesar $0,959 \geq 0,90$, dan nilai CFI sebesar 0.963 $\geq 0,90$ yang menunjukkan bahwa uji kesesuaian model dapat diterima dengan baik. Sehingga dalam penelitian ini dapat disimpulkan bahwa struktur analisis modeling dapat dilakukan.

Sesuai dengan path analysis gambar 4.28 maka diperoleh model struktural sebagai berikut

$$
\text { Kepuasan = 0,50 Citra Merek + 0,52 Kualitas Pelayanan + e24 }
$$

Loyalitas = 0,24 Citra Merek+0,15 Kualitas Pelayanan+e24+0,61 Kepuasan+ e25

Dapat diketahui dari analisis tersebut bahwa variabel kualitas pelayanan merupakan variabel yang berperan dominan dalam membentuk variabel kepuasan pelanggan dan variabel kepuasan pelanggan merupakan variabel dominan yang berperan membentuk variabel loyalitas pelanggan.

\section{HASIL UJI HIPOTESIS}

Kriteria goodness of fit model structural yang diestimasi dapat terpenuhi, maka tahap selanjutnya adalah analisis terhadap uji hipotesis dilakukan untuk merngetahui berpengaruh atau tidaknya variabel independen terhadap variabel dependen. Untuk menganalisis lebih jelas mengenai pengaruh citra merek, kualitas pelayanan dan kepuasan terhadap loyalitas pelanggan pengguna produk pos kilat khusus di Kantor Pos Kuningan tersaji pada tabel sebagai berikut : 
Tabel 1

Uji Pengaruh Variabel

Regression Weights: (Group number 1 - Default model)

\begin{tabular}{|c|c|c|c|c|c|c|c|}
\hline & & & $\begin{array}{c}\text { Estimat } \\
\mathrm{e}\end{array}$ & S.E. & C.R. & $\mathrm{P}$ & Label \\
\hline $\begin{array}{l}\text { KEPUASAN_PELAN } \\
\text { GGAN }\end{array}$ & $\begin{array}{l}<- \\
-\end{array}$ & CITRA_MEREK & .534 & .067 & 7.908 & $* * *$ & $\begin{array}{l}\text { par_2 } \\
0\end{array}$ \\
\hline $\begin{array}{l}\text { KEPUASAN_PELAN } \\
\text { GGAN }\end{array}$ & $\begin{array}{l}<- \\
-\end{array}$ & $\begin{array}{l}\text { KUALITAS_PELAY } \\
\text { ANAN }\end{array}$ & .498 & .061 & 8.123 & $* * *$ & $\begin{array}{l}\text { par_2 } \\
1\end{array}$ \\
\hline $\begin{array}{l}\text { LOYALITAS_PELA } \\
\text { NGGAN }\end{array}$ & $\begin{array}{l}<- \\
-\end{array}$ & $\begin{array}{l}\text { KUALITAS_PELAY } \\
\text { ANAN }\end{array}$ & .148 & .081 & 1.831 & 067 & $\begin{array}{l}\text { par_2 } \\
2\end{array}$ \\
\hline $\begin{array}{l}\text { LOYALITAS_PELA } \\
\text { NGGAN }\end{array}$ & $\begin{array}{l}<- \\
-\end{array}$ & CITRA_MEREK & .268 & .085 & 3.154 & 002 & $\begin{array}{l}\text { par_2 } \\
3\end{array}$ \\
\hline $\begin{array}{l}\text { LOYALITAS_PELA } \\
\text { NGGAN }\end{array}$ & $\begin{array}{l}<-- \\
- \\
\end{array}$ & $\begin{array}{l}\text { KEPUASAN_PELAN } \\
\text { GGAN }\end{array}$ & .627 & .128 & 4.886 & $* * *$ & $\begin{array}{l}\text { par_2 } \\
4\end{array}$ \\
\hline
\end{tabular}

Sumber : Hasil Olah data SEM Amos 24 Tahun 2018

Analisis uji pengaruh dilakukan dengan uji t yang dimaksudkan untuk menguji pengaruh sebuah variabel eksogen terhadap sebuah variabel endogen atau pengaruh sebuah variabel endogen terhadap variabel endogen lainnya. Dengan kata lain uji ini bertujuan untuk menguji signifikansi pengaruh sebuah variabel yang mempengaruhi terhadap sebuah variabel lain yang dipengaruhi.

Hipotesis:

HO : Variabel yang mempengaruhi, tidak berpengaruh signifikan terhadap variabel yang dipengaruhi

H1: Variabel yang mempengaruhi, berpengaruh signifikan terhadap variabel yang dipengaruhi

Dasar pengambilan keputusan atas uji hipotesis tersebut adalah sebagai berikut :

- Jika nilai probalitasnya (nilai sig) $>0.05$ atau - $\mathrm{t}$ tabel $<\mathrm{t}$ hitung $<\mathrm{t}$ tabel maka $\mathrm{H} 0$ diterima

- Jika nilai probalitasnya (nilai sig) $<0.05$ atau $\mathrm{t}$ hitung $<-\mathrm{t}$ tabel atau $\mathrm{t}$ hitung $>\mathrm{t}$ tabel maka $\mathrm{H} 0$ ditolak

Berdasarkan tabel 4.39 diperoleh keterangan hasil pengujian hipotesis sebagai berikut:

\section{H1 = Terdapat pengaruh signifikan antara Citra Merek terhadap Kepuasan Pelanggan.}

Berdasarkan hasil penelitian diketahui bahwa pengaruh antara Citra Merek dengan Kepuasan Pelanggan terdapat nilai CR sebesar 7.908 dengan signifikansi yang diperoleh $0,000<0,001$ ( $\mathrm{P}=* * *)$ lebih kecil dari 0,05 dengan koefisien standardized 0,067. Maka H1 diterima, artinya terhadap pengaruh yang positif dan signifikan antara Citra Merek dengan Kepuasan Pelanggan.

H2 = Terdapat pengaruh signifikan antara Kualitas Pelayanan terhadap Kepuasan Pelanggan

Berdasarkan hasil penelitian diketahui bahwa pengaruh antara Kualitas Pelayanan dengan Kepuasan Pelanggan terdapat nilai CR sebesar 8.123 dengan signifikansi yang diperoleh $0,000<0,001(\mathrm{P}=* * *)$ lebih kecil dari 0,05 dengan koefisien standardized 0,061. Maka H1 diterima, artinya terdapat pengaruh yang positif dan signifikan antara Kualitas Pelayanan terhadap Kepuasan Pelanggan.

H3 = Terdapat pengaruh signifikan antara kepuasan pelanggan terhadap loyalitas pelanggan

Berdasarkan hasil penelitian diketahui bahwa pengaruh antara Kepuasan Pelanggan dengan Loyalitas Pelanggan terdapat nilai CR sebesar 4.886 dengan signifikansi yang diperoleh $0,000<0,001(\mathrm{P}=* * *)$ lebih kecil dari 
Indonesian Journal Of Strategic Management

Vol 3, Issue 2, Agustus 2020

0,05 dengan koefisien standardized 0,128. Maka H1 diterima, artinya terdapat pengaruh yang positif dan signifikan antara Kepuasan Pelanggan terhadap Loyalitas Pelanggan.

H4 = Terdapat pengaruh signifikan antara Citra Merek terhadap Loyalitas Pelanggan

Berdasarkan hasil penelitian diketahui bahwa pengaruh antara Citra Merek dengan Loyalitas Pelanggan terdapat nilai CR sebesar 3.154 dengan signifikansi yang diperoleh 0,002 $(\mathrm{P}=0.002)$ lebih kecil dari 0,05 dengan koefisien standardized 0,085. Maka H1 diterima, artinya terdapat pengaruh yang positif dan signifikan antara Citra Merek terhadap Loyalitas Pelanggan.

H5 = Terdapat pengaruh signifikan antara Kualitas Pelayanan terhadap Loyalitas Pelanggan

Berdasarkan hasil penelitian diketahui bahwa pengaruh antara Kualitas pelayanan dengan Loyalitas Pelanggan terdapat nilai CR sebesar 1.831 dengan signifikansi yang diperoleh 0,067 ( $\mathrm{P}=0.067)$ lebih besar dari 0,05 dengan koefisien standardized 0,081. Maka H1 ditolak dan $\mathrm{H0}$ diterima, artinya tidak terdapat pengaruh yang positif dan signifikan antara Kualitas Pelayanan terhadap Loyalitas Pelanggan.

\section{H6 = Secara bersama-sama citra merek dan kualitas pelayanan memiliki pengaruh signifikan terhadap kepuasan pelanggan.}

Berdasarkan hasil penelitian diketahui bahwa pengaruh antara Citra Merek, Kualitas pelayanan terhadap Kepuasan Pelanggan di dijelaskan dalam persamaan regresi sebagai berikut :

Kepuasan Pelanggan $=0.496$ Citra Merek + 0.516 Kualitas Pelayanan

Standardized Regression Weights: (Group number 1 - Default model)

\begin{tabular}{|lll|r|}
\hline & & & $\begin{array}{r}\text { Esti } \\
\text { mat } \\
\mathrm{e}\end{array}$ \\
\hline KEPUASAN_P & $<-$ & CITRA_MER & .496 \\
ELANGGAN & -- & EK & \\
KEPUASAN_P & $<-$ & KUALITAS_P & .516 \\
ELANGGAN & -- & ELAYANAN & \\
\hline
\end{tabular}

p-ISSN 2614-5391, e-ISSN 2614-2406

https://journal.uniku.ac.id/index.php/ijsm

Sumber : Hasil Olah data SEM Amos 24 Tahun 2018

Sehingga di peroleh nilai $\left(\mathrm{R}^{2}\right)$ dengan besarnya nilai koefisien determinasi ditunjukkan oleh nilai Squared Multiple Correlation sebagai berikut :

Squared Multiple Correlations: (Group number 1 - Default model)

\begin{tabular}{|lr|}
\hline & Estimate \\
\hline KEPUASAN_PELANGGAN & .799 \\
\hline
\end{tabular}

Sumber : Hasil Olah Data AMOS 24 Tahun 2018

Dapat dijelaskan bahwa nilai estimate Squared Multiple Correlation sebesar 0.799 yang berarti $\mathrm{H} 1$ diterima maka terdapat pengaruh yang positif dan signifikan antara Citra Merek, Kualitas Pelayanan terhadap Kepuasan Pelanggan

\section{H7 = Secara bersama-sama citra merek dan kualitas pelayanan memiliki pengaruh signifikan terhadap loyalitas pelanggan.}

Berdasarkan hasil penelitian diketahui bahwa pengaruh antara Citra Merek, Kualitas pelayanan terhadap Loyalitas Pelanggan di dijelaskan dalam persamaan regresi sebagai berikut :

Loyalitas Pelanggan $=0.547$ Citra Merek + 0.467 Kualitas Pelayanan +0.613 Kepuasan

Standardized Regression Weights: (Group number 1 - Default model)

\begin{tabular}{|c|c|c|}
\hline & & $\begin{array}{l}\text { Esti } \\
\text { mate }\end{array}$ \\
\hline $\begin{array}{l}\text { LOYALITAS_PE } \\
\text { LANGGAN }\end{array}$ & $\begin{array}{ll}<-- & \text { KUALITAS_PE } \\
- & \text { LAYANAN }\end{array}$ & .467 \\
\hline $\begin{array}{l}\text { LOYALITAS_PE } \\
\text { LANGGAN }\end{array}$ & $\begin{array}{ll}<-- & \text { CITRA_MERE } \\
- & \mathrm{K}\end{array}$ & .547 \\
\hline
\end{tabular}

Sehingga di peroleh nilai $\left(\mathrm{R}^{2}\right)$ dengan besarnya nilai koefisien determinasi ditunjukkan oleh nilai Squared Multiple Correlation sebagai berikut :

Squared Multiple Correlations: (Group number 1 - Default model)

\begin{tabular}{|lr|}
\hline & Estimate \\
\hline LOYALITAS_PELANGGAN & .803 \\
\hline Sumber : Hasil Olah Data AMOS & 24 Tahun 2018
\end{tabular}


Indonesian Journal Of Strategic Management Vol 3, Issue 2, Agustus 2020

Dapat dijelaskan bahwa nilai estimate Squared Multiple Correlation sebesar 0.803 yang berarti H1 diterima maka terdapat pengaruh yang positif

\section{Kesimpulan}

Berdasarkan pembahasan yang telah diuraikan pada bab sebelumnya serta berdasarkan data yang penulis peroleh dari penelitian maka dapat ditarik kesimpulan sebagai berikut :

1. Secara keseluruhan berdasarkan hasil penilaian responden variabel citra merek, loyaitas pelanggan, kepuasan pelanggan dan loyalitas pelanggan berada pada tahap penilaian baik. Hal tersebut terjadi karena Kantor Pos Kuningan berorientasi pada kepuasan pelanggan dan berupaya mencapai loyalitas pelanggan.

2. Varibel citra merek secara parsial berpengaruh positif dan signifikan terhadap kepuasan pelanggan. Jika variabel citra merek meningkat maka kepuasan pelanggan ikut meningkat.

3. Variabel kualitas pelayanan secara parsial berpengaruh positif dan signifikan terhadap kepuasan pelanggan. Jika kualitas pelayanan meningkat maka kepuasan pelanggan ikut meningkat.

4. Variabel kepuasan pelanggan secara parsial berpengaruh positif dan signifikan terhadap loyalitas pelanggan. Jika kepuasan pelanggan meningkat maka loyalitas pelanggan ikut meningkat.

5. Varibel citra merek secara parsial berpengaruh positif dan signifikan terhadap loyalitas pelanggan. Jika variabel citra merek meningkat maka loyalitas pelanggan ikut meningkat.

6. Variabel kualitas pelayanan secara parsial tidak berpengaruh signifikan terhadap loyalitas pelanggan. Jika kualitas pelayanan meningkat maka belum tentu loyalitas pelanggan dapat tercapai.

7. Secara simultan citra merek dan kualitas pelayanan berpengaruh positif terhadap kepuasan pelanggan.
p-ISSN 2614-5391, e-ISSN 2614-2406

https://journal.uniku.ac.id/index.php/ijsm

dan signifikan antara Citra Merek dan Kualitas Pelayanan terhadap Loyalitas Pelanggan.

Jika secara bersama-sama citra merek dan kualitas pelayanan meningkat, maka kepuasan pelanggan ikut meningkat.

8. Secara simultan citra merek dan kualitas pelayanan berpengaruh positif terhadap loyalitas pelanggan. Jika secara bersama-sama citra merek dan kualitas pelayanan meningkat, maka loyalitas pelanggan dapat tercapai.

\section{Saran}

Adapun saran yang penulis berikan untuk perbaikan dan sebagai masukan pada manajemen Kantor Pos Kuningan adalah sebagai berikut :

1. Untuk meningkatkan citra merek positif dimata pelanggan pos seyogyanya manajemen pos kantor pos kuningan membentuk tim kreatif untuk mempublikasikan hal-hal yang positif terkait dengan operasional kantor pos yang mampu menjadi informasi baik dan mampu menarik minat pelanggan pos untuk terus melakukan transaksi menggunakan produk pos kilat khusus.

2. Manajemen Kantor pos seyoganya membentuk PIC yang fokus pada complain handling dan layanan pos jemput kiriman yang tidak tertumpu pada petugas Customer Service, sehingga mempermudah pelanggan saat akan menggunakan produk jasa pengiriman kantor pos secara online.

3. Manajemen Kantor Pos Kuningan disarankan untuk lebih meningkatkan kualitas pelayanan, yang tidak terfokus pada tampilan fisik gedung, peralatan modern, keramahan petugas, dan lain sebagainya, Melainkan untuk dapat lebih focus pada pengelolaan kecepatan pengiriman, kemanan isi kiriman dan fokusa pada hal-hal 
Indonesian Journal Of Strategic Management Vol 3, Issue 2, Agustus 2020

yang bersifat mengutamakan kepentingan pelanggan.

4. Untuk menarik pelanggan menjadi loyal, seyogyanya dilakukan sistem pembinaan pelanggan melalui informasi penyampaian kiriman pos yang cepat dan akurat, adanya point reward bagi pelanggan berulang kali menggunakan jasa pengiriman produk pos kilat khusus.

5. Manajemen Kantor Pos Kuningan seyognyanya membuat satu sistem

\section{DAFTAR PUSTAKA}

Arshad, T., Zahra, R., dan Draz, U. (2016), "Impact of Customer Satisfaction on Image , Trust, Loyalty and the Customer Switching Behavior in Conventional and Islamic Banking : Evidence from Pakistan" American Journal of Business and Society, Vol. 1, No. 3, hlm 154-165

Bayraktar, E., Tatoglu, E., Turkyilmaz, A., Delen, D., dan Zaim, S. (2012), "Measuring the efficiency of customer satisfaction and loyalty for mobile phone brands with DEA". Expert Systems with Applications, Vol.1 No. 39, hlm 99-106.

Beerli, A., Martin, J,D., dan Quintana, A. (2004). A Model of Customer Loyalty in The Retail Banking Market. European Journal of Marketing.

Gaspersz, V. (2011). Total Quality Management untuk Praktisi Bisnis dan. Industri, Bogor,Vinchristo Publication.

Ghozali, I. (2017), Model Persamaan Struktural Konsep dan Aplikasi Dengan Program AMOS 24, Edisi 7, Semarang : Badan Penerbit Universitas Diponegoro.

Griffin, J. (2010), Customer Loyalty, Edisi Revisi, Jakarta : Erlangga Barata.

Huang, K.Y., Kuo, Y.W., dan Xu, S.W. (2009), "Applying importance-performance analysis to evaluate logistic service quality for online shopping among retailing
p-ISSN 2614-5391, e-ISSN 2614-2406

https://journal.uniku.ac.id/index.php/ijsm

yang mengikuti perkembangan jaman seperti sistem jejak lacak kiriman secara online pada mobile phone, pengecekan tarif kiriman yang dilakukan secara online dan mudah, serta update pengetahuan pos, terutama pada barang-barang yang tidak diperbolehkan dikirim ketika menggunakan produk pos kilat khusus.

delivery", International Journal on Electronic Business Management, Vol. 7 No.2 hlm 128 - 136.

Inamullah dan Khan. (2012), Impact of Customers Satisfaction And Customers Retention on Customer Loyalty, International Journal of Scientific \& Technology Research, Vol. 1, No.2, hlm 106-110.

Jasfar, F. (2009), Manajemen Jasa Pendekatan Terpadu. Bogor : Ghalia.

Khasanah, Imroatul, O., dan Dina, P. (2010), Analisis Pengaruh Kualitas Pelayanan Terhadap Kepuasan Konsumen RS St. Elisabeth Semarang, Universitas Diponegoro, Vol.12, No.2, hlm 1-16.

Kheng, L. L., Mahamad, O., Ramayah, T., dan Mosahab, R. (2010), "The Impact of Service Quality on Customer Loyalty: A Study of Banks in Penang, Malaysia". International Journal of Marketing Studies, Vol.2, No.2, hlm 57-66.

Koo, D, M.(2013). Inter-relationships among Store I mages, Store Satisfaction, and Store Loyalty among Korea Discount Retail Patrons, Asia Pacific Journal of Marketing and Logistics.1Vol.5, No.4, hlm 42-71.

Johanudin, L. Nur, S.R., Noraslinda, M.S., Salleh, M.R., dan Razlan, A.Z. (2015), A Study of Brand Image towards Customer's Satisfaction in the Malaysian Hotel 
Indonesian Journal Of Strategic Management

Vol 3, Issue 2, Agustus 2020

Industry, International Research Symposium in Service Management, IRSSM-6, hlm 11-15.

Justin, P., Arun, Mittal,G.,dan Srivastav. (2016), Impact of Service Quality on Customer Satisfaction in Private and Public Sector Banks, International Journal of Bank Marketing, Vol. 34, No. 5, hlm 01-30.

Kasali, R. (2013), Manajemen Public Relations Konsep dan Aplikasinya di. Indonesia, Jakarta: Pustaka Utama Grafiti.

Kotler, P., dan Keller, K.L. (2007), Manajemen Pemasaran, Edisi ke 13, Jilid 1 Jakarta: Erlangga.

Kotler, P., dan Keller ,K.L. (2009), Manajemen Pemasaran, Edisi ke 14, Jilid 1, Jakarta: ,Erlangga.

Lehtinen,U., dan Lehtinen,J.R. (1982). Service Quality: A Study of Quality Dimensions. (Service Management Institude).

Lonardo, Soelasih, Y.(2014), Analisis Pengaruh Kualitas Produk, Harga, dan Lingkungan Fisik Perusahaan Kue Lapis Legit XYZ Terhadap Kepuasan Konsumen Dalam Membangun Word Of Mouth.

Lovelock, C., Jochen W., dan Jacky,M. (2011), Pemasaran Jasa, edisi 7, Jakarta: Erlangga.

Lupiyoadi, dan Hamdani, A. (2015), Manajemen Pemasaran Jasa, Edisi Ke 2 , Jakarta: Erlangga.

Qauman, N.S,. Siti, A., dan Anie, E.K. (2016), Pengaruh citra merek (brand image) terhadap loyalitas konsumen, Jurnal IlmuIlmu Peternakan, Vol. 26, No.3, hlm 20 26.

Ramesh, N.(2015), The Effects Of Brand Image On Customer Satisfaction And Loyalty Intention In Retail Super Market Chain Uk, International Journal of Social Sciences
p-ISSN 2614-5391, e-ISSN 2614-2406 https://journal.uniku.ac.id/index.php/ijsm

and Management, Vol.2, No.1, hlm 20912986.

Rishi, K., dan Deepak, J. (2017), The Impact Of Perceived Service Quality Dimensions On Customer Satisfaction: An Empirical Study On Public Sector Banks In India, International Journal of Bank Marketing, Vol. 35 No. 3, hlm 01-36.

Rangkuti, F. (2009), Strategi Promosi yang Kreatif dan Analisis Kasus Integrated Marketing Communication, Jakarta : PT. Gramedia Pustaka.

Saladin, D. (2007), Manajemen Pemasaran, Bandung: Linda Karya.

Sasongko, F., dan Subagio,H. (2013), Pengaruh Kualitas Layanan Terhadap Kepuasan Pelanggan Restoran Ayam Penyet Ria, Universitas Kristen Petra. Jurnal Manajemen Pemasaran Petra Vol. 1, No. 2, hlm 1- 7.

Schiffman, L.G, dan Kanuk, L.L. (2012). Perilaku konsumen. Edisi 9, Jakarta: Indeks.

Shimp, A., Terence. (2014), Komunikasi Pemasaran Terpadu dalam periklanan dan Promosi, Jakarta: Salemba Empat.

Simamora, B. (2008), Panduan Riset Perilaku Konsumen, Cetakan Ketiga, Jakarta: PT.Gramedia Pustaka.

Soeling, dan Pantius D. (2007). Pertumbuhan Bisnis dan Tanggung jawab sosial perusahaan. Jurnal Ilmu Administrasi dan Organisasi, Bisnis \& Birokrasi, Vol. 15, No 1.

Sugiyono. (2017), Metode Penelitian Kuantitatif, Kualitatif, dan R\&D, Bandung: Alfabeta. 